\title{
Study Of The Effect Of Addition Of Butone Granular Asphalt 5/20 On Marshall Characteristics Of Hot Mix Asphalt AC-WC
}

\author{
M. Iqbal Zaihan Batubara \\ Department Of Civil Engineering, University Of North Sumatra, Jl. Dr. Mansur No. 9 Padang Bulan, Kec. \\ Medan Baru, Kota Medan 20222
}

\begin{tabular}{|c|c|}
\hline ARTICLE INFO & ABSTRACT \\
\hline Article history: & \multirow{4}{*}{$\begin{array}{l}\text { As buton product that is currently being developed is Asbuton type } \\
\text { BGA or called Buton Granular Asphalt which has bitumen content } \\
\text { between } 20-25 \% \text { (Puslitbang Prasarana Transport Dep.PU, 2005). } \\
\text { BGA has been used in several locations but its use is considered not } \\
\text { optimal, therefore the authors want to examine how the effect of } \\
\text { variations in the level of addition of asbuton material on the } \\
\text { performance of asphalt mixtures. In this study, testing was carried } \\
\text { out in stages, starting with material testing consisting of aggregate } \\
\text { testing (coarse, fine, filler), as well as asphalt property testing and } \\
\text { BGA material testing. Then a mixture of Marshall test objects will be } \\
\text { made to be tested. The mixed test method used is the Marshall } \\
\text { method which will then produce parameter values in the form of VFB } \\
\text { (Void Filled Bitumen), Stability, Residual Stability, VIM (Void in Mix), } \\
\text { VMA (Void Mineral Aggregate), flow, and MQ (Marshall Quotionent). } \\
\text { The purpose of this study was to determine the effect of adding } \\
\text { variations in the use of BGA type } 5 / 20 \text { materials, namely } 0 \%, 3 \% \\
\text { and } 5 \% \text { on Marshall characteristics of AC-WC hot asphalt mixture } \\
\text { using the } 2010 \text { Binamarga Specification Revision } 3 \text {. The results } \\
\text { showed that the addition of Asbuton Item } 5 / 20 \text { significantly increased } \\
\text { the value of stability, residual stability and MQ along with increasing } \\
\text { levels of asbuton used, but did not significantly affect the value of } \\
\text { VMA, VFB and Flow and concluded that the use of Asbuton BGA } \\
\text { with a level of } 3 \% \text { has produced optimal results. }\end{array}$} \\
\hline $\begin{array}{r}\text { Received Feb 06, } 2021 \\
\text { Revised Mar 15, } 2021 \\
\text { Accepted Apr 30, } 2021\end{array}$ & \\
\hline Keywords: & \\
\hline $\begin{array}{r}\text { Marshall Test } \\
\text { Asbuton Point 5/20 } \\
\text { Stability } \\
\text { Specifications } 2010 \text { Rev.3 } \\
\text { AC-Wc asb }\end{array}$ & \\
\hline
\end{tabular}

This is an open access article under the CC BY-NC license.

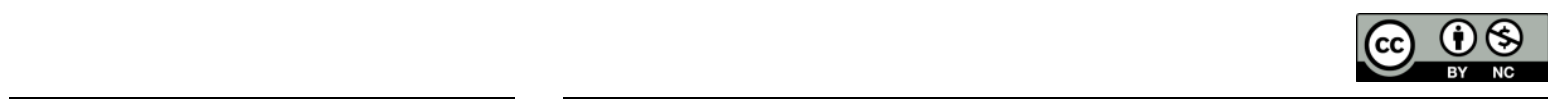

\section{Corresponding Author:}

M. Iqbal Zaihan Batubara, Department Civi Engineering, University Of North Sumatra, Jl. Dr. Mansur No. 9 Padang Bulan, Kec. Medan Baru, Kota Medan 20222.

Email : zaihanbatubara@gmail.com

\section{INTRODUCTION}

Along with the increase in the asphalt road network in Indonesia, it is necessary to have road pavements that have high durability and quality. This can be achieved by the addition of additives that can improve the performance of the pavement mixture. The need for asphalt for road pavement purposes is currently also quite high in Indonesia. In 2008, the demand for asphalt was supported by asphalt imports by Pertamina and reached 200,000 to 250,000 tons. While on the other hand, actually Indonesia has quite a lot of natural asphalt reserves on the island of Buton, Southeast Sulawesi Province. This asphalt is known as Asbuton or Buton Stone Asphalt.
\end{abstract}


Asbuton product which is currently being developed is Asbuton type BGA or called Buton Granular Asphalt which has bitumen content between 20-25\% (Puslitbang for Transportation Infrastructure, Ministry of Public Works, 2005). BGA has been used in several locations even though its use is not optimal, BGA is one of the processed asbuton products that contains high aromatic and resinous ingredients so that it can increase adhesion (anti-stripping) and increase the flexibility of the mixture which serves to increase stiffness with sufficient flexibility limits to withstand traffic loads without experiencing damage outside the plan (Balitbang PU, 2009).

Research on the effect of using granular Asbuton (BGA) on hot asphalt wear mixtures has already been carried out, such as the study of BGA type $5 / 25$ with special specifications from the Ministry of Public Works 2007 by Layuk, Paku (2014), Laboratory Design of HRS-WC with BGA as an additive by Howard et al (2008). So in this study, we want to know how the variation in the level of use of BGA type 5/20 material on the Marshall characteristics of AC-WC hot asphalt mixture using the 2010 Binamarga Specification Revision 3.

\section{RESEARCH METHOD}

This type of research is an experimental research. The laboratory used was the Highway Laboratory of the University of North Sumatra, to carry out testing of asphalt properties, while the process of making Marshall test objects, Marshall testing, BGA Type 5/20 properties testing, and aggregate properties testing were carried out in a laboratory owned by PT. Tidy Arjasa.

\subsection{The Design and Manufacturing Phase of Marshall Test Items}

Two stages were held to make Marshall test specimens, stage 2 Marshall test specimens were made after the optimum asphalt content was obtained from the Marshall Test Phase 1. The specimens were without the addition of BGA and the specimens with the addition of variations in the levels of BGA in the bitumen content at intervals of $0,5 \%(4.5 \%, 5 \%, 5.5 \%, 6 \%, 6.5 \%)$, and the PRD test (Balance density). So that obtained a total of 54 test objects. In Phase 2, the specimens were manufactured using the same mix design and with bitumen content in accordance with the optimum asphalt content obtained from the Marshall test phase I.

At this stage, 9 Marshall specimens and 9 specimens for the Retained Marshall Test will be made, so that a total of 18 specimens will be obtained to determine the Marshall characteristics of $\mathrm{KAO}$ in each variation of $\mathrm{BGA}$ levels.

\subsection{Marshall Test Stage}

A stage was held to test the Marshall test object which consisted of 2 stages, using the SNI 06-2489-1990 method. In the first stage of the test, stage I test specimens were carried out using the Marshall Apparatus set, to obtain Marshall 1 characteristic data which was useful for determining the optimum asphalt content in each test variable, namely BGA content of $0 \%, 3 \%$ and $5 \%$. In the Phase 2 Test (After KAO) Phase 2 test objects were carried out using the Marshall Apparatus set, to obtain Marshall characteristic data that was useful for retesting the results of each test variable, namely BGA levels of $0 \%, 3 \%$ and $5 \%$ on asphalt conditions. optimum. Then the Marshall Residual test was carried out to obtain the residual stability value on the test object after being immersed for 24 hours at a temperature of $60 \mathrm{oC}$.

\section{RESULTS AND DISCUSSIONS}

\subsection{Material Properties Test Results}

In the property test, an inspection is carried out for all materials that make up the AC-WC laston mixture. The results of the properties test were obtained from the examination of the characteristics of the aggregate, the results of the examination of the characteristics of the asphalt, and the results of the examination of the characteristics of the BGA:

\section{a. Aggregate Characteristics examination results}


The results of the examination of the characteristics of the aggregates give the percentage value of passing (\%) for each filter (Table.1), the value of the specific gravity of the aggregate (Table 2), and the Abrasion value of $21.58 \%$.

Table 1. Aggregate Sieve Analysis Test Results

\begin{tabular}{cllcll}
\hline $\begin{array}{c}\text { Filter } \\
\text { Number }\end{array}$ & CA & MED & $\begin{array}{c}\text { Pass Result (\%) } \\
\text { CD }\end{array}$ & NS & Fillers (PC) \\
\hline 3/4" & 100.00 & 100.00 & 100.00 & 100.00 & 100.00 \\
$1 / 2 "$ & 50.54 & 100.00 & 100.00 & 100.00 & 100.00 \\
$3 / 8 "$ & 5.74 & 90.62 & 97.62 & 100.00 & 100.00 \\
$\# 4$ & 1.81 & 36.27 & 81.98 & 99.50 & 100.00 \\
$\# 8$ & 1.55 & 10.19 & 81.98 & 94.09 & 100.00 \\
$\# 16$ & 1.45 & 6.94 & 50.83 & 82.65 & 100.00 \\
\#30 & 1.39 & 5.94 & 33.62 & 63.71 & 100.00 \\
$\# 50$ & 1.33 & 5.34 & 26.47 & 42.61 & 100.00 \\
$\# 100$ & 1.23 & 4.19 & 14.30 & 10.34 & 100.00 \\
\#200 & 0.22 & 1.83 & 8.39 & 3.04 & 100.00 \\
\hline
\end{tabular}

Source: Research Results (2017)

\section{b. Asphalt Characteristics Examination Results}

From this examination, the values of asphalt penetration, softening point of asphalt, flash point of asphalt, weight loss, ductility and specific gravity were obtained, as presented in Table 3.

Table 2. Asphalt Characteristic Inspection Results

\begin{tabular}{lllllll}
\hline Checking type & Unit & Method & \multicolumn{2}{c}{ Specification } & \multicolumn{2}{c}{ Status } \\
& & & Min & Max & Results \\
& & & & & \\
\hline Asphalt penetration & $0.1 \mathrm{~mm}$ & SNI 06-2456-1991 & 60 & 70 & 64.8 & Worthy \\
Asphalt softening point & C & SNI 2434:2011 & 48 & - & 48 & Worthy \\
Asphalt flash point & C & SNI 2433:2011 & 232 & - & 320 & Worthy \\
Loss of asphalt weight & \% Heavy & SNI 06-2411-1991 & - & 0.8 & 0.19 & Worthy \\
ductility & cm & SNI 2432:2011 & 100 & - & 115 & Worthy \\
Specific gravity & gram/cc & SNI 2441:2011 & 1 & - & 1.04 & Worthy \\
\hline
\end{tabular}

Source: Research Results (2017)

\section{c. BGA Characteristics Examination Results}

Check up result BGA characteristics give the value of BGA bitumen contenttable 3 , as well as the percentage value of passing (\%) in each sieve (Table 4).

Table 3. BGA Characteristics Examination Results

\begin{tabular}{|c|c|c|c|c|c|c|}
\hline Inspection & Unit & Method & Spe & ication & Results & Status \\
\hline & & & Min & Max & & \\
\hline Asphalt penetration & $0.1 \mathrm{~mm}$ & SNI 06-2456-1991 & 4 & 7 & 5 & Worthy \\
\hline Asphalt content in asbuton & $\%$ & SNI 03-6894-20 & 19 & 22 & 20.15 & Worthy \\
\hline
\end{tabular}

\subsection{Results of the Mixed Test Object}

The method of analysis (analysis of more than 3 fractions) is used with the formula (2.2) to determine the percentage of each fraction used. Because BGA has an insoluble (mineral) content, the more BGA is used, the reduction/substitution of fine mineral aggregate (CD) and filler with mineral grains contained in BGA is carried out, the ratio of the percentage of total fine aggregate and coarse aggregate remains the same for all test variables. 


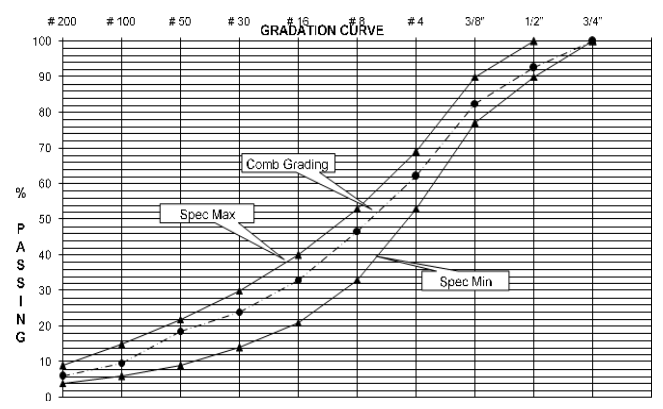

Figure 1. Gradation of Combination of BGA Combined Aggregate 0\% Source: Research Results (2017)

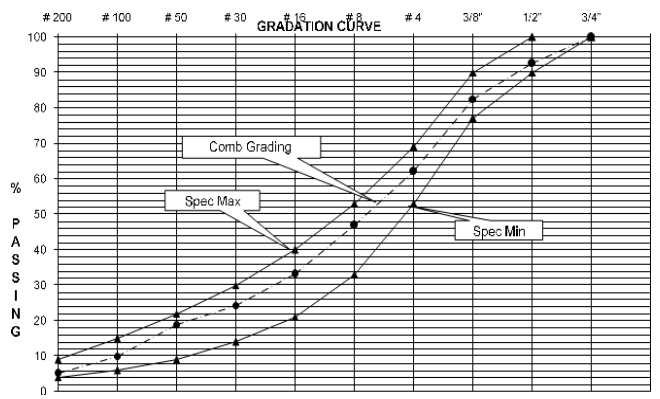

Figure 2. Gradation Graph of Combined Aggregate Combination of BGA 3\% Source: Research Results (2017)

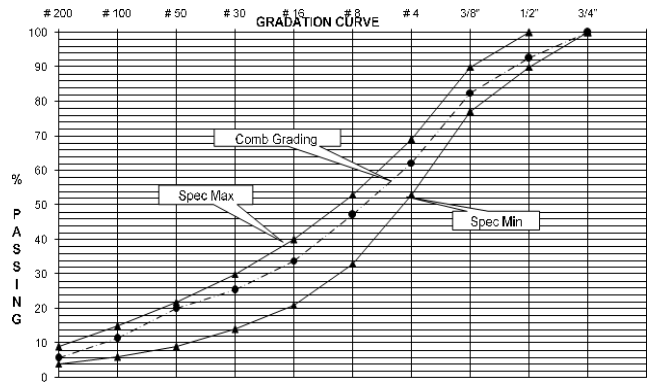

Figure 3. Gradation Graph of Combined Aggregate Combination of BGA 5\% Source: Research Results (2017)

In determining the optimum asphalt content, the formula (2.1) is used, namely $\mathrm{Pb}=0.035$ $(\% \mathrm{CA})+0.045(\% \mathrm{FA})+0.18(\%$ Filler $)+$ Constant, a constant with a value of 1 . The calculation results are presented in Table 4.

Table 4. Results of Determination of Planned Optimum Asphalt Content (Pb)

\begin{tabular}{cccccc}
\hline BGA & CA & FA & Fillers & Total & Pb \\
\hline $\mathbf{0} \%$ & 53.24 & 40.77 & 5.98 & 100 & 5.78 \\
$\mathbf{3 \%}$ & 53.17 & 40.78 & 6.04 & 100 & 5.78 \\
$\mathbf{5 \%}$ & 52.89 & 39.80 & 7.31 & 100 & 5.96 \\
\hline
\end{tabular}

Source: Research Results (2017)

\subsection{Marshall Test Object Test Results (Before KAO)}


The results of the calculation of all Marshall parameters for stage testing (Before KAO) can be seen in Table 5.

Table 5. Marshall Test Results (Before KAO)

\begin{tabular}{|c|c|c|c|c|c|c|}
\hline \multirow[t]{2}{*}{ Variant } & \multirow[t]{2}{*}{ Parameter } & \multicolumn{5}{|c|}{ Asphalt Level } \\
\hline & & $4.5 \%$ & $5.0 \%$ & $5.5 \%$ & $6.0 \%$ & $6.5 \%$ \\
\hline \multirow{6}{*}{ 0\% BGA } & VIM & 5.59 & 5.17 & 4.52 & 4.19 & 3.69 \\
\hline & VMA & 15.61 & 16.27 & 16.73 & 17.46 & 18.04 \\
\hline & Flow & 3.37 & 3.53 & 3.63 & 3.53 & 3.57 \\
\hline & steady & 839.9 & 945.1 & 1014.0 & 1002.2 & 987.0 \\
\hline & $\mathbf{M Q}$ & 244.59 & 262.24 & 273.60 & 278.07 & 271.31 \\
\hline & VFB & 64.15 & 68.21 & 72.98 & 75.99 & 79.54 \\
\hline \multirow{7}{*}{$3 \%$ BGA } & VIM & 5.53 & 5.23 & 4.77 & 4.38 & 4.04 \\
\hline & VMA & 15.53 & 16.30 & 16.92 & 17.59 & 18.30 \\
\hline & Flow & 3.47 & 3.37 & 3.43 & 3.57 & 3.63 \\
\hline & steady & 1090.5 & 1172.2 & 1188.9 & 1216.9 & 1169.9 \\
\hline & $M Q$ & 308.39 & 341.36 & 339.49 & 334.49 & 315.67 \\
\hline & VFB & 64.36 & 67.89 & 71.79 & 75.09 & 77.94 \\
\hline & VIM & 5.79 & 5.27 & 4.92 & 4.54 & 4.26 \\
\hline \multirow{5}{*}{$5 \%$ BGA } & VMA & 15.73 & 16.30 & 17.01 & 17.69 & 18.45 \\
\hline & Flow & 3.57 & 3.30 & 3.50 & 3.60 & 3.62 \\
\hline & steady & 1124.0 & 1192.5 & 1238.4 & 1280.7 & 1242.8 \\
\hline & $M Q$ & 308.95 & 354.28 & 346.89 & 348.78 & 336.26 \\
\hline & VFB & 63.21 & 67.66 & 71.07 & 74.35 & 76.93 \\
\hline
\end{tabular}

Source: Research Results (2017)

\subsection{Analysis of Test Object Design Results}

In this study, each level of BGA variation has the same coarse aggregate combination gradation design but the higher the level of BGA usage, the reduction in the use of fine aggregate, in this case Stone Ash (Crushing Dust) and filler, therefore obtained the design of the test object in the form of $15 \%(\mathrm{CA}), 35 \%(\mathrm{MA}), 36 \%(\mathrm{CD}), 12 \%$ (NS), 2\% (Cement) for BGA test variables $0 \%$, $15 \%(\mathrm{CA}), 35 \%$ (MA), 35.6\% (CD ), 12\% (NS), 2.4\% (Mineral Asb.) for BGA test variables 3\%, and $15 \%$ (CA), 35\% (MA), 34\% (CD), 12\% (NS), 4\% ( Mineral Asb.) for 5\% BGA test variable. This design has complied with the AC-WC gradation set by the 2010 Binamarga Specification Revision 3 . To determine the optimum level of the plan, the Pb BGA values were $0 \%, 3 \%, 5 \%$ respectively, at $5.78 \%, 5.78 \%$, and $5.96 \%$.

\subsection{Marshall Test Results Analysis (Before KAO)}

To determine the optimum asphalt content (KAO) used levels that meet all Marshall parameters, then based on the test results obtained at BGA values of $0 \%, 3 \%, 5 \%$, respectively, $5.85 \%, 5.9 \%$, and $6 \%$, these results are considered meet because the value is higher than the optimum asphalt content of the plan (Pb). It was found that the higher the use of BGA, the higher the asphalt requirement to achieve the optimum value.

\subsection{Marshall Test Results Analysis (After KAO)}

From the results of the Marshall test, it was found that the mixture of hot asphalt with added BGA $5 / 20$ as much as $0 \%, 3 \%, 5 \%$ with KAO had met the Marshall characteristics specified in the 2010 Binamrga Specifications Rev.3. From this test, the results of the analysis are as follows:

a. In stability parameters, the use of BGA $0 \%, 3 \%$ and $5 \%$ has complied with the Laston AC-WC and Laston Mod specifications. AC-WC determined by the 2010 Binamarga Specification Revision 3 and obtained an increase in stability of the mixture added with BGA $3 \%$ by $21.54 \%$ and an increase of $21.73 \%$ in the mixture of $5 \%$ BGA. Based on the results of the analysis, it was concluded that the higher levels of BGA use had a positive impact on the stability value. This is in accordance with the research of Martha (2012), but with the type of BGA 20/25 and the addition of polymer type additives.

b. The increase in the MQ parameter is $20.29 \%$ in the mixture with $3 \% B G A$ and $21.4 \%$ in the mixture with $5 \% \mathrm{BGA}$, this can be caused by the low penetration value of the bitumen contained in the BGA and therefore has an impact on a stiffer mixture. The MQ parameters obtained from the test have met the requirements of the Revision 3 Binamrga Specifications. 
c. From the test results, it can be seen that the addition of BGA affects the VIM and VMA values, so that if the higher levels of BGA use in a mixture will have an impact on increasing the VIM (Void in Mix) and VMA values in a mixture.

d. For Flow and VFB parameters, the use of BGA 5/20 has complied with the 2010 Binamarga Specification Revision 3, but it does not appear to have a significant impact.

e. From the Marshall Residual test, it can be seen that the mixture with the addition of BGA produces a percentage of the residual marshall value which tends to be higher than the mixture without the addition of BGA, namely $91.3 \%$ for the $3 \%$ BGA mixture and $92.8 \%$ for the $5 \%$ BGA mixture.

\section{CONCLUSION}

In stability parameters, the use of BGA $0 \%, 3 \%$ and $5 \%$ has complied with the Laston AC-WC and Laston Mod specifications. AC-WC determined by the 2010 Binamarga Specification Revision 3 and obtained an increase in stability of the mixture added with BGA $3 \%$ by $21.54 \%$ and an increase of $21.73 \%$ in the mixture of $5 \%$ BGA. Based on the results of the analysis, it was concluded that the higher levels of BGA use had a positive impact on the stability value. This is in accordance with the research of Martha (2012), but with the type of BGA 20/25 and the addition of polymer type additives.

The increase in the MQ parameter is $20.29 \%$ in the mixture with $3 \% \mathrm{BGA}$ and $21.4 \%$ in the mixture with $5 \% \mathrm{BGA}$, this can be caused by the low penetration value of the bitumen contained in the BGA and therefore has an impact on a stiffer mixture. The MQ parameters obtained from the test have met the requirements of the 2010 Binamarga Specification Revision 3.

From the test results, it can be seen that the addition of BGA affects the VIM and VMA values, so that if the higher levels of BGA use in a mixture can have an impact on increasing the VIM (Void in Mix) and VMA values in a mixture.

For Flow and VFB parameters, the use of BGA 5/20 has complied with the 2010 Binamarga Specification Revision 3, but it does not appear to have a significant impact.

From the Marshall Residual test, it can be seen that the mixture with the addition of BGA produces a percentage of the residual marshall value which tends to be higher than the mixture without the addition of BGA, namely $91.3 \%$ for the $3 \%$ BGA mixture and $92.8 \%$ for the $5 \%$ BGA mixture.

The use of BGA affects the optimum asphalt content value. In this study, using the same percentage of fine aggregate and coarse aggregate, it was found that the higher the level of BGA usage, the higher the optimum asphalt content value was found than the mixture without BGA.

\section{REFERENCES}

Sukirman, S., (1999). Perkerasan Lentur Jalan Raya, Penerbit Nova, Bandung. Sukirman, S., (2003). Campuran Beraspal Panas, Penerbit Granit, Bandung.

Hardiyatmo, Hary (2011), Perancangan Perkerasan Jalan dan Penyelidikan tanah, Penerbit UGM, Yogyakarta. Prawira, Abdi. et al. (2008), Pemanfaatan BGA (Buton Granular Asphalt) sebagai bahan pengganti agregat halus pada campuran HRS-WC secara Laboratorium..Forum Teknik Sipil , No.XVIII/2-5-08.

A.Martha K (2012), Analisis Kinerja Campuran Aspal Panas dengan menggunakan Variasi Komposisi BGA (Buton Granular Asphalt) dan penambahan aditif jenis polimer. Universitas Indonesia.

Agah, H.R (2011), Pengaruh Penambahan Buton Granular Asphalt pada Campuran Beton Aspal Terhadap Modulus Resilien dan Gradasi. Jurnal Transportasi Vol.12 No.2 Agustus 2012: 103-112.

Arief, Dimas (2008), "Pengaruh Penggunaan Buton Granular Asphalt (BGA) 15/20 terhadap karasteristik Marshall campuran AC-WC". Universitas Jember.

Panduan Praktikum Laboratorium Jalan Raya Departemen Teknik Sipil, Fakultas Teknis, Universitas Sumatera Utara. Indonesia.

Bukhari dkk, (2007), Rekayasa Bahan dan Tebal perkerasan, Fakultas Teknik, Universitas Syiah Kuala, Banda Aceh.

Kreb, D,. 1978, Highway Material, Mc.Grawth Hill, Singapore.

Direktorat Jenderal Bina Marga (2010). Spesifikasi Umum Bidang Jalan dan Jembatan Divisi 6 Perkerasan Beraspal. Pusat Litbang Jalan dan Jembatan Badan Penelitian dan Pengembangan, Bandung. 
Direktorat Jenderal Bina Marga, (2006), Skh.6.3.a.1: Spesifikasi Khusus Campuran Panas dengan Asbuton. Pusat Litbang Jalan dan Jembatan Badan Penelitian dan Pengembangan, Bandung. 